\title{
Editorial
}

\section{KEY FACTORS IN WASTE MANAGEMENT SYSTEMS AND THEIR VISIBILITY}

Waste generation is inevitably connected to the socio-economic status of a region or country. Increasing population, rapid urbanization, increasing economic activity and an increase in society's living standards, mainly in major cities, has led to substantial growth in global waste generation. Specific socio-economic conditions prevail in developing countries, including rapid population growth, rural-urban migration, lack of funds and low-skilled cheap labour. Sustainable waste management (SWM) systems in emerging economies often lack facilities, and suffer insufficient service coverage, improper disposal and treatment methods that can lead to major environmental and social problems.

Direct adoption of developed cities' approaches without proper consideration of the local circumstances may lead to unsustainable future waste management in developing cities (Mukhtar et al., 2016). The significance of SWM factors in developing countries has been evaluated in many studies according to specific contexts including: socio-economic impacts on waste generation, recycling, waste to resource initiatives, the collection of municipal waste and disposal of waste. The roles of specific factors are not always well-defined nor their influence measured.

Multiple factors affect the development of SWM, including legislative, environment, social, technical, health, market demand and economic aspects. These key factors need to be identified and their role(s) understood to ascertain whether proposed waste management plans are duly tailored to local requirements and are viable in environmental, social and economic terms. The key factors relevant to waste management systems can vary due to the differences between individual cities' characteristics.

Some factors are usually measurable by specific indicators or scales, quantifiable, considered in decision-making and implementation processes, and publically accessible (e.g. demographic indicators): these factors may be termed "visible". In contrast, there are "invisible" factors that not usually measured or quantified but still likely to influence waste generation, behaviour and operational practices, and perceptions about waste. These factors potentially influence the need for development of a waste management system but are qualitative (e.g. behaviour, understanding and awareness) and may be important if local conditions are to be recognised and addressed in the design and implementation of waste management systems.
Various factors in SWM play different fundamental roles in waste management practices. These include: policy and strategy, age and aging communities, community behaviour and interactions, the socio-economic impacts on waste generation, recycling, waste to resource initiatives, the collection and disposal of municipal waste. The degree of influence of invisible factors is perhaps varied and sometimes unclear in terms of impact. Nevertheless, in principle they serve as a starting point to design more effective waste management strategies or policies based on tangible local trends or evidence, rather than adopting best practices from elsewhere which may not address local characteristics, customs, uniqueness or waste composition.

A comprehensive list of 43 fundamental SWM factors, derived from the literature and classified according to the PESTLE (political, environmental, social, technological, legal and economic) system. are summarised in Table 1. They were evaluated by global experts from developed and developing countries via a Delphi survey to determine whether they were considered as visible or invisible in practice.

The global experts agreed on the classification of 24 factors. Experts from developing countries classified 27 factors as visible whilst those from developed countries classified 20 factors as visible. There was agreement that 15 factors are visible: local government plan, government priorities, seasonal variations, local/national events, skilled workers and experts, application of suitable technology, facilities availability, international directives, local policies, producers responsibility, relevant SWM law, incentives from waste, availability of funds, interest and tax, and incentives. There was agreement that 8 factors are invisible: corruption, influence of politicians, environmental guidelines, environmental targets, religion, ethnicities, discrimination and philosophical change.

There was also agreement in that no clear consensus was observed for the rate of technology change. Thus, experts from developed and developing countries generally agreed on the visibility of environmental, technological, legal and economic factors, suggesting that these four categories have emerged as important. The classification of political and social factors showed less consistency between developing and developed countries; social and political factors are important but difficult to measure or assess because of their complexity.
Detritus / Volume 15 - 2021 / pages 1-2

https://doi.org/10.31025/2611-4135/2021.15109

(c) 2021 Cisa Publisher. Open access article under CC BY-NC-ND license 
TABLE 1: Summary of fundamental factors that are important in the development of SWM according to developed, developing countries and their matched factors between both types of countries.

\begin{tabular}{|c|c|c|c|}
\hline PESTLE class & Developed countries & Developing countries & Overall matched \\
\hline Political & $\begin{array}{l}\text { Local government plan } \\
\text { Government priorities }\end{array}$ & $\begin{array}{l}\text { Government stability } \\
\text { Local government plan } \\
\text { Government priorities } \\
\text { Bureaucracy }\end{array}$ & $\begin{array}{l}\text { Local government plan } \\
\text { Government priorities }\end{array}$ \\
\hline Environmental & $\begin{array}{l}\text { Environmental guidelines } \\
\text { Environmental targets } \\
\text { Environmental awareness }\end{array}$ & $\begin{array}{l}\text { Environmental guidelines } \\
\text { Environmental targets } \\
\text { Geographical landform } \\
\text { Environmental awareness }\end{array}$ & $\begin{array}{l}\text { Environmental guidelines } \\
\text { Environmental targets } \\
\text { Environmental awareness }\end{array}$ \\
\hline Social & $\begin{array}{l}\text { Seasonal variations } \\
\text { Resource consumption patterns } \\
\text { Socio-demographic indicator }\end{array}$ & $\begin{array}{l}\text { Resource consumption patterns } \\
\text { Rural-urban migration } \\
\text { Socio-demographic indicator } \\
\text { Seasonal variations } \\
\text { Cultural } \\
\text { Local national events } \\
\text { Attitude behavior gap } \\
\text { Resistance to change }\end{array}$ & $\begin{array}{l}\text { Seasonal variations } \\
\text { Resource consumption patterns } \\
\text { Socio-demographic indicator }\end{array}$ \\
\hline Technological & $\begin{array}{l}\text { Skilled workers and experts } \\
\text { Application to suitable technology } \\
\text { Facilities availability } \\
\text { Research and development }\end{array}$ & $\begin{array}{l}\text { Skilled workers and experts } \\
\text { Application to suitable technology } \\
\text { Facilities availability } \\
\text { Research and development } \\
\text { Rate of technology change }\end{array}$ & $\begin{array}{l}\text { Skilled workers and experts } \\
\text { Application to suitable technology } \\
\text { Facilities availability } \\
\text { Research and development }\end{array}$ \\
\hline Legal & $\begin{array}{l}\text { International directives } \\
\text { Local policy } \\
\text { Producers responsibility } \\
\text { Relevant SWM law }\end{array}$ & $\begin{array}{l}\text { Local policy } \\
\text { Producers responsibility } \\
\text { Consumer accountability } \\
\text { Relevant SWM law }\end{array}$ & $\begin{array}{l}\text { Local policy } \\
\text { Producers responsibility } \\
\text { Relevant SWM law }\end{array}$ \\
\hline Economic & $\begin{array}{l}\text { Availability of funds } \\
\text { Trade restrictions on waste } \\
\text { Economic growth patterns } \\
\text { Incentives } \\
\text { Interest and tax }\end{array}$ & $\begin{array}{l}\text { Availability of funds } \\
\text { Trade restrictions on waste } \\
\text { Third sector restrictions } \\
\text { Economic growth patterns } \\
\text { Interest and tax } \\
\text { Incentives }\end{array}$ & $\begin{array}{l}\text { Availability of funds } \\
\text { Trade restrictions on waste } \\
\text { Economic growth patterns } \\
\text { Interest and tax } \\
\text { Incentives }\end{array}$ \\
\hline
\end{tabular}

From the above it is clear the need to adopt new perspectives in the selection of factors considered in the development and optimisation of local waste management systems. By definition, invisible factors are not currently recognised as contributors to waste management systems, and even though they may be locally very important, they may have been neglected in decision-making processes. Recognising and making use of selected invisible factors within a local context may hasten the implementation and effectiveness of initiatives taken towards the development of SWM systems.

Factors in waste management may vary in influence and change dynamically alongside urbanization; this dynamic varies from one country to another and so factors need to be re-evaluated periodically. Different combinations of factors influence the development of SWM systems. Alongside the use of a reliable evidence-base, ad- dressing the factors - visible and/or invisible - that strongly influence local conditions is crucial if municipalities in developed and developing countries are to move towards more effective, locally optimised sustainable waste management systems.

Erni M. Mukhtar ${ }^{1}$, Ian D. Williams ${ }^{1}$ and Peter J. Shaw ${ }^{2}$

${ }^{1}$ Faculty of Engineering and Physical Sciences, University of Southampton, Southampton, Hampshire, S017 1BJ, UK

${ }^{2}$ Faculty of Environmental and Life Sciences, University of Southampton, Highfield Campus, University Road, Southampton S017 1BJ, UK

\section{REFERENCE}

Mukhtar, E.; Williams, I.D.; Shaw, P.J and Ongondo, F. (2016). A tale of two cities: The emergence of urban waste systems in a developed and a developing city. Recycling, 1, 254-270. http://dx.doi. org/10.3390/recycling1020254. 